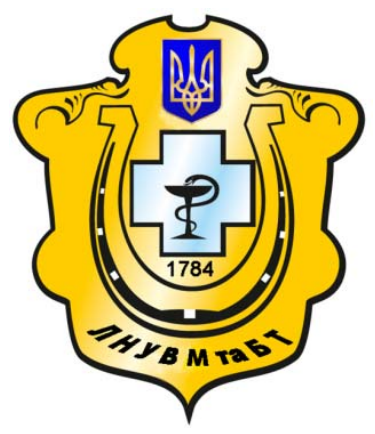

Науковий вісник Львівського національного університету ветеринарної медицини та біотехнологій імені С.3. Гжицького

Scientific Messenger of Lviv National University of Veterinary Medicine and Biotechnologies named after S.Z. Gzhytskyj

doi:10.15421/nvlvet7733

ISSN 2518-7554 print

ISSN 2518-1327 online

$\underline{\text { http://nvlvet.com.ua/ }}$

УДК 619:519.16:612.664:636.2

\title{
Залежність відтворної здатності корів від тривалості лактації
}

\author{
Ю.С. Масалович, В.Й. Любецький \\ masalovich@nubip.edu.ua, akusherstvo@nubip.edu.ua \\ Національний університет біоресурсів і природокористування Украӥни, \\ вул. Героїв Оборони, 11, м. Київ, 03041, Україна
}

Вивчено залежність критеріїв відтворної здатності корів від тривалості лактації. Тривалість лактаційного періоду (300-450 діб) для високопродуктивних корів є оптимальною для: сервіс-періоду, індексу осіменіння, міжстельного інтервалу та виходу телят. В середньому по господарствах середня тривалість сервіс-періоду суттєво не відрізнялася між собою та не залежала від системи утримання корів і становила $302 \pm 60,9$ та $307 \pm 61,3$ діб відповідно. Подібна тендениія закономірно прослідковується і в показниках міжстельного інтервалу. Подовження тривалості лактачії корів негативно відображається на показниках їх відтворної здатності та економічних даних. Загальні витрати на одну тварину від додаткових осіменінь та недоотримання телят були найвищими у третіх дослідних групах і становили 1458 і 1946 грн відповідно. Встановлено, щзо тривалість лактаційного періоду впливає на показники відтворної функиії корів.

Ключові слова: корови, відтворення, заплідненість, індекс осіменіння, сервіс-період, лактація, сухостій, отел, продуктивність.

\section{Зависимость воспроизводительной способности коров от продолжительности лактации}

\author{
Ю.С. Масалович, В.И. Любецкий \\ masalovich@nubip.edu.ua, akusherstvo@nubip.edu.ua \\ Национальный университет биоресурсов и природопользования Украины, \\ ул. Героев Обороны, 11, Киев, 03041, Украина
}

\begin{abstract}
Изучена зависимость критериев воспроизводительной способности коров от продолюжительности лактации. Продолжительность лактачионного периода (300-450 суток) для высокопродуктивных коров является оптимальной для: сервиспериода, индекса осеменения, межотельного интервала и выхода телят. В среднем по хозяйствам средняя продолжительность сервис-периода существенно не отличалась между собой и не зависела от системы содержания коров и составила $302 \pm 60,9$ и $307 \pm 61,3$ суток соответственно. Подобная тенденция закономерно прослеживается и в показателях межотельного интервала. Увеличение продолжительности лактаиии коров негативно отражается на показателях их воспроизводительной способности и экономических данных. Общие затраты на одно животное от дополнительных осименений и недополучения телят были самыли высокими в третьих исследовательских группах и составили 1458 и 1946 грн соответственно. Установлено, что продолжстельность лактационного периода влияет на показатели воспроизводительной функции коров.
\end{abstract}

Ключевые слова: коровы, воспроизводство, оплодотворяемость, индекс осеменения, сервис-период, лактация, сухостой, отел, продуктивность.

Citation:

Masalovych, Y.S., Liubetskyi, V.I. (2017). Reproductive capability of cows depending on lactation duration. Scientific Messenger LNUVMBT named after S.Z. Gzhytskyj, 19(77), 153-157. 


\title{
Reproductive capability of cows depending on lactation duration
}

\author{
Y.S. Masalovych, V.I. Liubetskyi \\ masalovich@nubip.edu.ua, akusherstvo@nubip.edu.ua \\ National University of life and environmental sciences of Ukraine, \\ Heroyiv Oborony Str., 11, Kyiv, 03041, Ukraine
}

The dependence of the criteria of the reproductive ability of cows on the duration of lactation was studied. The duration of the lactation period (300-450 days) for highly productive cows is optimal for: the service period, the insemination index, the interval interval and the exit of the calves. On average, on farms, the average duration of the service period did not differ significantly between them and did not depend on the system of cows' content and amounted to $302 \pm 60.9$ and $307 \pm 61.3$ days, respectively. A similar tendency can be naturally traced in the parameters of the inter-interval interval. The increase in lactation time of cows negatively affects the indicators of their reproductive capacity and economic data. The total costs for one animal from additional changes and shortages of calves were the highest in the third research groups and amounted to 1458 and 1946 UAH. according. It is established that the duration of the lactation period affects the reproductive performance of cows

Key words: cows, reproduction, impregnation capacity, insemination index, service period, lactation, interlactation period, calving, productive.

\section{Вступ}

Ефективне молочне скотарство значною мірою залежить від інтенсивності відтворення стада, що відчутно впливає як на виробництво молока, так і на темпи генетичного прогресу селекційних ознак, які мають економічне значення (Masalovych and Liubetskyi, 2016). Низька відтворна здатність корів $€$ однією 3 великих проблем у сучасному молочному скотарстві (Havrylenko and Sharapa, 2008).

$€$ багато думок щодо критеріїв відтворення корів. Прихильники одного напрямку (за продуктивності 2,5-3 тис. кг молока за лактацію) вважають, що фізіологічний перебіг післяродового інтервалу завершується упродовж першого місяця, наполегливо утверджують і відстоюють ідею осіменіння і запліднення корів у перший місяць після родів як основної умови отримання протягом року від кожних 100 корів 110 115 телят і збільшення середньорічної молочної продуктивності на 10-18\% (Nezhdanov et al., 2008).

Інші дослідники стверджують, що інволюційні процеси в статевих органах корів закінчуються не раніше за 45-60 добу після родів, опираючись на дані низької їх запліднюваності в ці строки, наполегливо рекомендували (і продовжують рекомендувати) здійснювати перше штучне осіменіння тварин не раніше ніж 60 діб після отелу, запевнюючи, що тільки такий підхід до відтворення дасть можливість забезпечити найменший сервіс-період, міжотельний інтервал, маючи найкращі економічні показники щодо запліднюваності та молочної продуктивності тварин (Pipenko, 2002; Sudarev, 2008; Lebed'ko et al., 2009). До речi, зазначений показник 60 діб сьогодні у високотоварних господарствах вважають за оптимальний період добровільного очікування.

Результати більшості досліджень свідчать, що довший період добровільного очікування краще відображається на запліднюваності корів. Найімовірніше, це пов'язано з повним відновленням морфологічного стану матки та позитивним енергетичним балансом. Упродовж восьми досліджень, проведених ще на початку 70-х роках минулого століття, вчені довели, що заплідненість корів поліпшується в міру збільшення тривалості сервіс-періоду (Servah and Oleksievich, 2011). По-різному ставляться до цього питання і за кордоном. В Північній Америці на першому місці стоїть молочна продуктивність та збільшення сервісперіоду до розумної межі рахується нормальним. В Європі через пільги на виробництво молока та збільшення імпорту нетелів прагнуть утримати міжотельний період в рамках одного року (Servah and Oleksievich, 2011).

Із огляду на викладене, дослідження теоретичних i практичних основ проблеми інтенсивного відтворення стада залишається актуальним і потребує більш глибокого вивчення та наукового обгрунтування.

Мета дослідження - дослідити вплив тривалості лактації на деякі показники відтворення корів.

\section{Матеріал і методи дослідження}

Дослідження проводили упродовж 2016 року на коровах Української чорно-рябої молочної породи, в двох господарствах з різним типом утримання (господарстві № 1 прив’язна система, № 2 - безприв’язна). Залежно від тривалості лактації у кожному 3 господарств було сформовано по три дослідних групи корів: №1 - 300-450 діб; № 2 - 451-600 діб; № 3 - 601900 діб.

Вихід телят на 100 корів визначали за формулою $\mathrm{T}=365 * 100 / \mathrm{M}$ : де Т - вихід телят; 365 - діб у році; $\mathrm{M}-$ міжотельний період; 100 - коефіцієнт для переведення у відсотки.

Відбір тварин проводили згідно з даними програми «Юнформ-Агрі», а статистичну обробку даних проводили за допомогою Microsoft excel 2010.

\section{Результати та їх обговорення}

В результаті проведених досліджень, щодо тривалості лактації у корів і показників відтворної здатності нами встановлено, у господарстві № 1 у тварин першої групи середня тривалість сервіс-періоду була найменшою для даного досліджуваного господарства і становила $95 \pm 17,3$ діб, другої та третьої дослідних груп $243 \pm 27,4$ та $567 \pm 44,7$ діб відповідно (табл. 1). 
Таблицяя 1

Показники відтворної здатності дослідного стада

\begin{tabular}{|c|c|c|c|c|c|c|}
\hline \multirow[b]{2}{*}{ Господарство } & \multirow[b]{2}{*}{ № групи } & \multicolumn{5}{|c|}{ Показники відтворної здатності } \\
\hline & & $\begin{array}{c}\text { Сервіс-період, } \\
\text { діб }\end{array}$ & $\begin{array}{c}\text { Міжотельний } \\
\text { інтервал, діб }\end{array}$ & $\begin{array}{c}\text { Індекс } \\
\text { осіменіння }\end{array}$ & Вихід телят, \% & Номер лактації \\
\hline \multirow{4}{*}{ №1 } & $\begin{array}{c}1 \\
(\mathrm{n}=15)\end{array}$ & $95 \pm 17,3$ & $377 \pm 17,3$ & $1,8 \pm 0,4$ & $97,6 \pm 4,44$ & $2,3 \pm 0,2$ \\
\hline & $\begin{array}{c}2 \\
(\mathrm{n}=15)\end{array}$ & $243 \pm 27,4$ & $525 \pm 27,4$ & $4,1 \pm 0,7$ & $70,1 \pm 3,44$ & $2,2 \pm 0,5$ \\
\hline & $\begin{array}{c}3 \\
(n=15)\end{array}$ & $567 \pm 44,7$ & $849 \pm 44,7$ & $4,9 \pm 1,3$ & $43,4 \pm 2,31$ & $1,0 \pm 0,1$ \\
\hline & $\begin{array}{c}\text { Середнє } \\
(\mathrm{n}=45)\end{array}$ & $302 \pm 60,9$ & $584 \pm 60,9$ & $3,6 \pm 0,6$ & $70,4 \pm 6,83$ & $1,8 \pm 0,2$ \\
\hline \multirow{4}{*}{ №2 } & $\begin{array}{c}1 \\
(n=15)\end{array}$ & $121 \pm 15,0$ & $403 \pm 15,0$ & $1,7 \pm 0,4$ & $91,0 \pm 3,28$ & $2,1 \pm 0,6$ \\
\hline & $\begin{array}{c}2 \\
(\mathrm{n}=10)\end{array}$ & $227 \pm 24,9$ & $509 \pm 24,9$ & $3,7 \pm 1,2$ & $72,2 \pm 3,52$ & $1,8 \pm 0,6$ \\
\hline & $\begin{array}{c}3 \\
(n=15)\end{array}$ & $546 \pm 32,2$ & $828 \pm 32,2$ & $7,0 \pm 0,7$ & $44,3 \pm 1,90$ & $1,4 \pm 0,4$ \\
\hline & $\begin{array}{c}\text { Середнє } \\
(\mathrm{n}=40)\end{array}$ & $307 \pm 61,3$ & $589 \pm 61,3$ & $4,2 \pm 0,8$ & $68,8 \pm 6,58$ & $1,8 \pm 0,3$ \\
\hline
\end{tabular}

У господарстві № 2 сервіс-період для першої групи становив $121 \pm 15,0$, для другої групи $-227 \pm 24,9$, а для третьої групи $546 \pm 32,2$ діб. У середньому в господарствах середня тривалість сервіс-періоду суттєво не відрізнялася між собою та не залежала від системи утримання корів і становила $302 \pm 60,9$ та 307 \pm 61,3 діб відповідно. Подібна тенденція закономірно прослідковується і в показниках міжотельного інтервалу.

Середні показники індексу осіменіння дослідних господарств суттєво не відрізнялися між собою і становили 3,6 \pm 0,6 та 4,2 $\pm 0,8$ відповідно (табл. 1). Але очевидною $є$ тенденція до зростання індексу осіменіння зі збільшенням тривалості лактації у тварин дослідних господарств (рис. 1, рис. 2).

Деталізуючи індекс осіменіння корів господарства № 1 (рис. 1), нами встановлено, що в першій групі всі тварини запліднилися максимально після третього осіменіння, при індексі осіменіння в групі 1,8 $\pm 0,4$. У тварин другої групи індекс осіменіння становив $4,1 \pm$ 0,7. Причому лише одна тварина даної групи запліднилась за першим осіменінням, а в інших індекс осіменіння був від 3-х до 6-ти. Індекс осіменіння корів третьої групи був 4,9 $\pm 1,3$. Серед них одна тварина запліднилась за другим осіменінням, 4-и за третім, 4-и за четвертим. Інші шість корів мали індекс осіменіння від 5-ти до 11-ти.
Вивчаючи індекс осіменіння корів господарства № 2 (рис. 2), нами встановлено, що в першій дослідній групі при індексі осіменіння по групі $1,7 \pm 0,4$ всі тварини запліднилися максимально після третього осіменіння. У тварин другої групи чотири тварини запліднились від п'ятого до сьомого осіменіння, а в інших шести корів даної групи індекс осіменіння був $2-3$, середній показник в групі становив $3,7 \pm 1,2$. Індекс осіменіння корів третьої групи був 7,0 $\pm 0,7$. Серед них по одній тварині запліднились за четвертим та п’ятим осіменінням відповідно. У інших тринадцяти корів спостерігався індекс осіменіння від 6-ти до 9-ти.

Узагальнюючи вищезазначені дані, нами встановлено, що тварини з першої групи характеризувалися низьким індексом осіменіння $(1,7-1,8)$, а в другій групі цей показник коливався у межах від 3,7-4,1.

Варто зазначити, що для тварин третьої групи із прив’язним утриманням (господарство № 1) цей показник був нижчим на 2,1, і становив 4,9 $\pm 1,3$ порівнянно 3 тваринами третьої групи із безприв'язним утриманням (господарство № 2) - 7,0 \pm 0,7, що, на нашу думку, обумовлено можливістю більш ефективного контролю фізіологічного стану корів та виявлення стадії збудження статевого циклу.

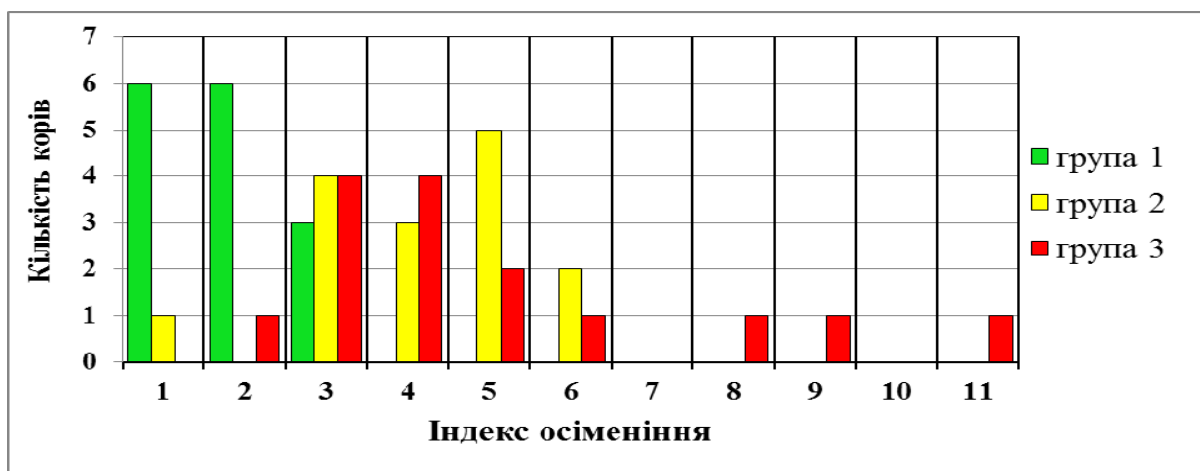

Рис. 1. Індекс осіменіння дослідних корів (господарство № 1) 


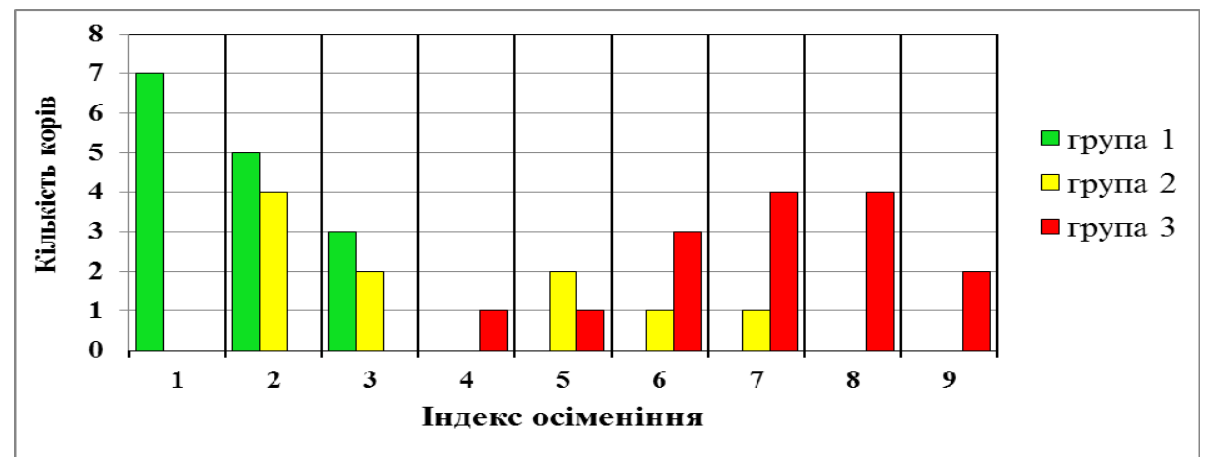

Рис. 2. Індекс осіменіння дослідних корів (господарство № 2)

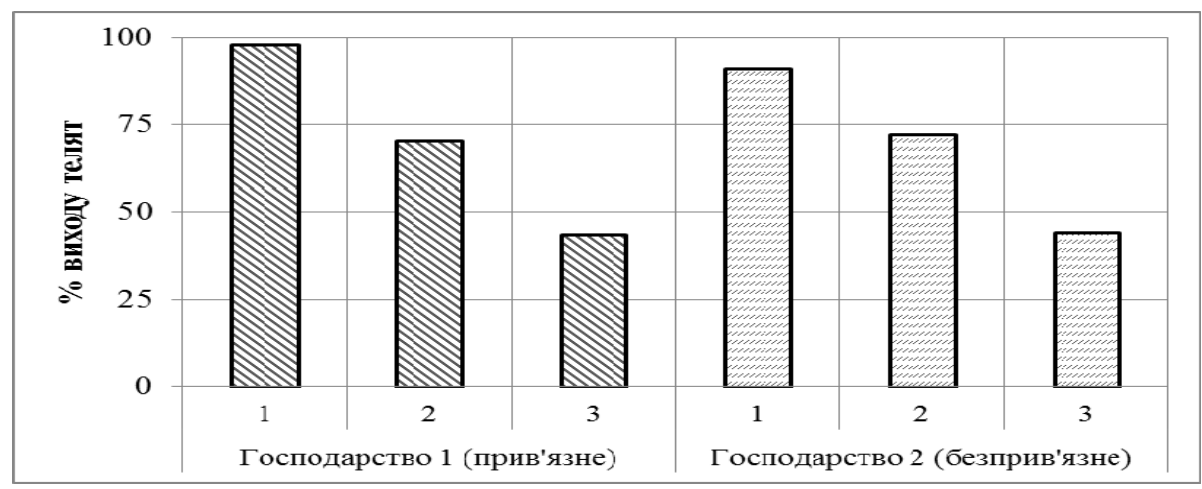

Рис. 3. Залежність виходу телят від тривалості лактації

Розрахувавши вихід телят залежно від тривалості міжотельного періоду, встановлено (табл. 1), що вихід телят у перших групах дослідних господарств наближався до $100 \%$, або від 100 корів можна отримати $91,0 \pm 3,28-97,6 \pm 4,44$ телят. У тварин других дослідних груп можливо отримати $70,1 \pm 3,44-72,2 \pm 3,52$ теляти, а третіх дослідних груп - 43,4 $\pm 2,31-44,3 \pm$ 1,90 відповідно. Нами встановлено, що тварини перших груп із тривалістю лактації 300-450 діб (рис. 3) мають оптимальні показники виходу телят на 100 корів, про що свідчить високий зворотній кореляційний зв'язок $\left(\mathrm{r}^{2}=-0,67--0,90\right)$.

Підраховуючи економічні збитки як результат додаткових осіменінь та недоотримання телят, у розра- хунку на 1 тварину нами було взято за базові показники для обрахунку: індексу осіменіння -1 (тобто одне осіменіння вважали за ідеал для всіх досліджуваних груп), а вихід телят - одне теля від однісї корови за один календарний рік (ціну теляти прирівнювали до одного центнера молока).

В результаті проведеного аналізу економічних збитків (рис. 4) в досліджуваних господарствах нами встановлено, що незначне збільшення індексу осіменіння на 0,8 та 0,7 відповідно у корів перших дослідних груп призвело до втрат 200 та 175 гривень, а витрати від недоотримання телят даних груп становили 26 та 83 гривні відповідно на одну тварину.

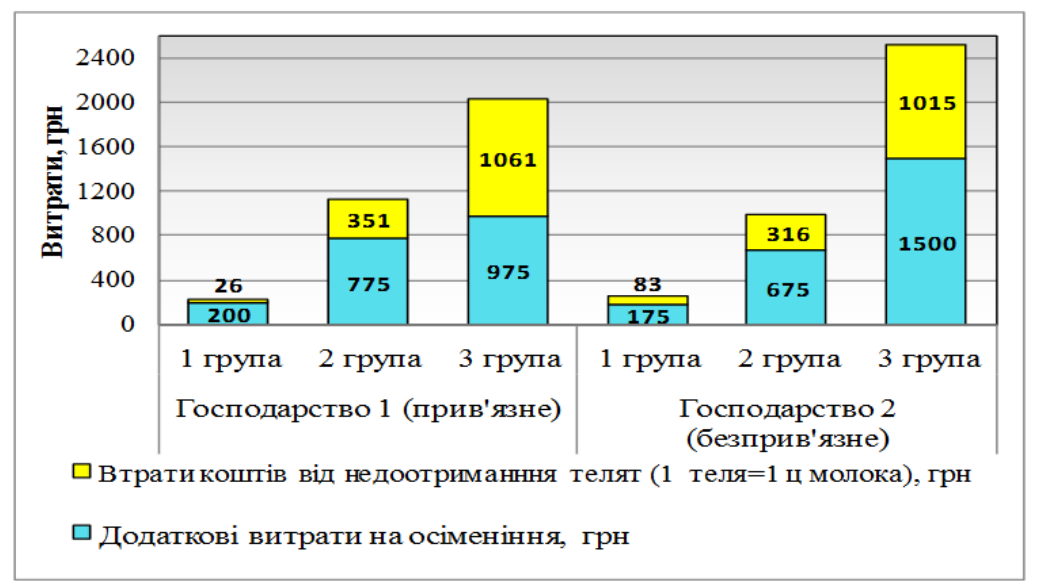

Рис. 4. Витрати на осіменіння та втрати коштів від недоотримання телят (у розрахунку на 1 тварину)

*вартість 1 спермодози - 250 грн;

**вартість 1 кг молока -8 грн 
Збільшення індексу осіменіння в других дослідних групах до 4,1 $\pm 0,7$ та 3,7 $\pm 1,2$ відповідно призвело до втрат на одну корову - 775 та 675 гривень, а витрати коштів від недоотримання телят становили 351 та 316 гривні відповідно.

У третіх дослідних групах індекс осіменіння був $4,9 \pm 1,3$ та 7,0 \pm 0,7, що відобразилось у додаткових витратах на запліднення однієї тварини - 975 та 1500 грн. Збитки від недотримання телят на одну тварину вищезазначених груп становили 1061 та 1015 гривень відповідно.

Підсумовуючи вищезазначене, варто зауважити, що загальні витрати на одну тварину від додаткових осіменінь та недоотримання телят були найвищими у третіх дослідних групах і становили 2036 і 2515 грн відповідно.

\section{Висновки}

1. Подовження тривалості лактації корів негативно відображається на показниках їх відтворної здатності та економічних даних.

2 Тривалість лактаційного періоду (300450 діб) для високопродуктивних корів є оптимальною для сервіс-періоду, індексу осіменіння, міжотельного інтервалу та виходу телят.

\section{Бібліографічні посилання}

Havrylenko, M.S., Sharapa, H.S. (2008). Vplyv hodivli ta utrymannia na vidtvoriuvalnu funktsiiu molochnykh koriv. Nauk. tekhn. bul. 96, 90-93 (in Ukrainian).

Lebed'ko, E., Torikova, E., Nikiforova, L. (2009). Udoi pervotelok zavisjat ot servis-perioda. Zhivotnovodstvo Rossii. 9, 37-38 (in Russian).

Masalovych, Yu.S., Liubetskyi, V.Y. (2016). Vplyv molochnoi produktyvnosti na vidtvoriuvalnu zdatnist koriv. Naukovyi visnyk. 237, 235-241 (in Ukrainian).

Nezhdanov, A., Sergeeva, L., Lobodin, K. (2008). Intensivnost' vosproizvodstva i molochnaja produktivnost' korov. Molochno-mjasnoe skotovodstvo. 5(2-4) (in Russian).

Pipenko, A. (2002). Idealnyi period dobrovilnoho ochikuvannia Vseukrainskyi zhurnal «Moloko i ferma». 6(13), 78-79 (in Ukrainian).

Servah, B., Oleksievich, E. (2011). Nuzhny nove ocenki vosproizvodstva. Zhivotnovodstvo Rossii. 8, 37-38 (in Russian).

Sudarev, N. (2008). Udoi i servis-period vzaimosvjazany. Zhivotnovodstvo Rossii. 3, 49-52 (in Russian).

Стаття надійшла до редакиії 15.03.2017 